\title{
Implementation of Mobile Banking in Bangladesh: Opportunities and Challenges
}

\author{
Md. Saifur Rahman Bhuiyan ${ }^{1}$, Md. Mizanur Rahman ${ }^{2}$ \\ ${ }^{1}$ Assistant Professor, Department of Business Administration, Metropolitan University, Sylhet, Bangladesh. \\ ${ }^{2}$ Senior Lecturer, Department of Business Administration, Metropolitan University, Sylhet, Bangladesh.
}

\begin{abstract}
Mobile banking is a newly added service in the banking sector that facilitates banking via mobile devices. With the tremendous growth in mobile phone usage, banks in the developed world have moved to utilize mobile banking, which makes banking easier, faster, and very cost-effective. Mobile phones have quickly emerged as a successful and popular means of communication in recent years and the researchers believe that growth of mobile banking in Bangladesh is inevitable, especially when banks do not have sufficient number of branches in the rural areas of Bangladesh. The purpose of this research is to assess the Opportunities and Challenges of mobile banking in this country. To accomplish this empirical study, multiple banks have been surveyed which either currently have an operational mobile banking in place or planning to introduce one in the near future. The research shows tremendous potential for mobile banking in Bangladesh and reveals some of the key barriers of progress as well.
\end{abstract}

KEYWORDS:Banking Sector, Mobile banking, Mobile Phone, Rural Areas, Telecommunication.

\section{Introduction}

In spite of the difficult business environment, the mobile communication is growing rapidly and cited as the fastest growing industry in Bangladesh. The numbers of current mobile subscribers in Bangladesh is about hundred million, which is roughly about $60 \%$ of the total population of the country ignoring the fact that many users in Bangladesh have multiple mobile phones. The use of mobile phone has rapidly grown across various categories of people regardless of their educational qualifications, financial capabilities, and technological backgrounds. Users have found various ways to make the best use of their phones and mobile banking is certainly one of those popular uses, which can provide added benefit to the users by combining the mobile phone's power of wireless communication and the financial services provided by banks. Mobile banking is a form of banking where funds are transferred through an exchange of electronic signals between financial institutions, rather than the exchange of cash, Cheques, or other negotiable instruments. The ownership of funds and transfer of funds between financial institutions are recorded on computer systems connected by mobile network or telephone lines. Customers use access codes such as a password or Personal Identification Number (PIN) instead of a signature on a cheque or a document. Mobile banking has been very successful and popular in the developed countries and this research shows that it has a great future in the developing countries as well. Being a developing country itself, Bangladesh can be certainly a prime example of successful implementation of mobile banking. So far banks have seen an exponential growth in the number of mobile banking users since the initial implementation and expect the growth to continue in the foreseeable future. The implementation of mobile banking has not progressed without its challenges and ensuring security and developing the sense of security among clients have been the biggest of all challenges.

\subsection{Aims and Scope}

The main objective of the study is three folded:

a) To assess the progress of the implementation of Mobile Banking in Bangladesh.

b) To verify the security and confidentiality of the system.

c) To examine the complexity of usage by the mobile banking users.

The research study is based on primary sources of data. For collecting the primary data fifty banking professionals, who were related with their banks' effort to introduce mobile banking and also uses the mobile banking services provided by their banks, were asked to complete a questionnaire. For this phase of the research, the scope was limited to branches located only in Sylhet division, however, it was ensured that at least one branch of each of the forty-seven private commercial banks was included in the research.

\subsection{Literature Review}

For over a decade, the rapid development in information and communication technology has significantly affected the banking industry. Financial sectors especially banking sector have improved their 
services through implementing various information technologies. Mobile phone is one of the most recognized and well accepted technologies not only in the developed countries but also in Bangladesh. Recently in Bangladesh it is observed that traditional branch banking is going to reduce due to the increase in mobile banking. Weber stated that "the use of mobile phones in order to effectuate banking transactions is bound to increase in a significant way in the near future. This growth in mobile financial services not only depends on technological advances, but also on consumer confidence in the provided services. Mobile financial services can be divided into mobile banking and mobile payment; therefore, legal certainty must be established as to what supervisory regime applies to the various activities involving banks and non-banks. Mobile banking activities fall within the scope of the banking business, and oversight is provided by the competent financial market authority for prudential supervision, if the definition of banking activities encompasses all relevant mobile banking activities. Furthermore, legal aspects also play a role in the evolution of mobile banking as far as the need to enhance customer trust in the offered services is concerned. Major issues arise in relation to data security and consumer protection. Moreover, the outsourcing of certain key activities to mobile operators deserves further attention, as mobile operators can, under specific circumstances, become deeply involved in mobile banking [1]." According to Donner, Jonathan, Tellez, and Camilo "the terms mobile banking, mpayments, $\mathrm{m}$-transfers, and $\mathrm{m}$-finance refer collectively to a set of applications that enable people to use their mobile telephones to manipulate their bank accounts, store value in an account linked to their handsets, transfer funds, or even access credit or insurance products [2]." Mobile banking is sometimes used as the alternative term of Electronic Banking. However, this is a misconception; E-banking actually covers a much bigger area than mobile banking which includes all forms of banking that involve electronic media. The development of mobile banking follows the same path of internet banking, another type of e-banking which uses almost identical technology and provides the backbone for mobile banking as well. For this reason Klein mentioned "mobile banking is growing at a remarkable speed around the world. In the process it is creating considerable uncertainty about the appropriate regulatory response to this newly emerging service. Researcher sets out a framework for considering the design of regulation of mobile banking. Since it lies at the interface between financial services and telecoms, mobile banking also raises competition policy and interoperability issues that are discussed in his paper. Finally, by unbundling payments services into its component parts, mobile banking provides important lessons for the design of financial regulation more generally in developed as well as developing economies[3]." Centeno provides an explanation that "the adaption of e-banking involves two main factors. The first one is the implementation of the related technology and the second factor is marketing and efficiency of products and services provided through mobile banking [4]" A bank may successfully introduce a very sophisticated mobile banking technology which is readily available to its clients but it may not be popular among the clients if the services provided through technology are not so useful. Researchers have identified many customer service related facilities provided by mobile banking. According to Mousumi and Jamil "PUSHPULL service offering SMS based mobile banking provides a new 24 hours banking convenience which helps customers stay on top of any recent changes made in their bank account, DPS or loan through their cell phone and provides multitasking opportunity [5]." At the same time Hasan, Baten, Kamil and Parveen indicated that "corporations [have] easier access to information as, they [check] on multiple accounts at the click of a button...E-banking [speeds] up cash cycle and increases efficiency of business processes as large variety of cash management instruments [are] available on Internet sites of banks [6]." Donner, Jonathan, Tellez, and Camilo add that "mobile banking costs less to send small amount of money at a great distance [2]". For instance, sending small amount of money through Banglalink mobile service is very quick and fairly reasonable which is preferred to a regular bank fund transfer that costs just about the same or even more and takes longer to reach the recipient. When it comes to transferring large funds, however people, prefer traditional bank transfer which is apparently more secure and reliable. In the developed world, mobile banking has provided additional convenience to the already well-established banking system. "For users in the developing world, on the other hand, the appeal of these mobile banking/m-payments systems may be less about convenience and more about accessibility and affordability. Taylor \& Francis Group argued that "in 2002, the total number of mobile (cellular) phones in use worldwide exceeded the number of landlines. Current projections suggest that the world will continue to add mobile lines faster than fixed lines; indeed, the next billion new phone users will use primarily mobiles [7]." Mobile Marketing Association has found that "the mobile banking market has grown significantly over the past several years, particularly in the United States, where many financial institutions now offer some form of mobile services for their customers. In France by 2013, it is expected that $42 \%$ of adults to use online banking, or more than 22 million people. With only $12 \%$ of Swedish banking customers using branches, Sweden has the lowest branch use in Europe. Swedish banks have successfully migrated the majority of their customers to ATMs and online banking - 83\% and 71\%, respectively...by $2012-2013,81 \%$ of Dutch and $47 \%$ of German consumers will use Internet banking [8]". Khan and Karim mentioned that "based on the scenarios in the developed countries we can anticipate a growing demand and usage of mobile banking in Bangladesh, especially, when there has been a high growth of mobile users and providers in Bangladesh in the 
recent years. The existing literature, however, suggests that "it is still not much available due to a number of constraints such as unavailability of a backbone network connecting the whole country; inadequacy of reliable and secure information infrastructure especially telecommunication infrastructure; sluggish ICT penetration in banking sector; insufficient legal and regulatory support for adopting e-banking and so on [9]."

In Bangladesh, the expansion of mobile banking is affected with several infrastructural, institutional, and regulatory constraints such as inadequate availability of reliable and secure telecommunication infrastructure, absence of a backbone network connecting the whole country, poor ICT penetration in the banking sector, lack of skilled manpower and training facilities, absence of supportive policies, guidelines, rules and regulations relating to e-transactions and the like. Despite the constraints, efforts by the Bangladesh Bank in modernizing the country's payment system and commitment by the government in building 'Digital Bangladesh' have brought competition among the scheduled banks to improve banking services and rapidly adopt mobile banking on a wider scale.

\subsection{Descriptive Analysis}

\section{Result and Discussion}

As per the design, the research reveals several details such as services provided by mobile banking, banking professional's view on security, list of companies that currently provide this service, companies' forecast on future growth.

Table 1. Different Services Provided Through Mobile Banking

\begin{tabular}{|l|l|l|l|l|l|}
\hline & Deposit & Withdrawal & Money Transfer & Foreign Remittance & $\begin{array}{l}\text { Checking } \\
\text { balance }\end{array}$ \\
\hline Mean & 0.40 & 0.38 & 0.56 & 0.40 & 0.98 \\
\hline Standard Error & 0.07 & 0.07 & 0.07 & 0.07 & 0.02 \\
\hline Variance & 0.24 & 0.24 & 0.25 & 0.24 & 0.021 \\
\hline
\end{tabular}

The above table shows that almost all of the respondents use the Checking Balance service; hence, we can assume that this is the most popular service provided by mobile banking. However, we should note that all of the other services such as deposit, withdrawal, money transfer, and foreign remittance are also fairly used by consumers.

Table 2.Security of Mobile banking

\begin{tabular}{|l|c|c|}
\hline Total Respondents & $\mathbf{4 7}$ & $\mathbf{1 0 0 \%}$ \\
\hline Highly secured & 25 & $53.20 \%$ \\
\hline Fairly Secured & 18 & $38.30 \%$ \\
\hline Neither Secured nor Unsecured & 4 & $8.50 \%$ \\
\hline Fairly Unsecured or Highly Unsecured & 0 & $0 \%$ \\
\hline
\end{tabular}

It is surely encouraging that more that $90 \%$ of the respondents believe, as table 2 indicates, that mobile banking is either highly or fairly secured and it must be noted that most them believes it is highly secured. It is also very encouraging that none of the respondents thinks mobile banking is unsecured and only a very little percentage of the respondents have a neither favorable nor unfavorable opinion. So one may think that the issue of security is perhaps not an issue after all but before rushing to that conclusion one should look at the next finding about the confidentiality of the Personal Identification Number (PIN).

Table 3. Possibility to Access User's PIN by Another Users

\begin{tabular}{|l|c|c|}
\hline & Safeties of PIN & $\mathbf{1 0 0 \%}$ \\
\hline Total Response & $\mathbf{4 6}$ & $21.74 \%$ \\
\hline Next to Impossible & 10 & $19.56 \%$ \\
\hline Very Difficult & 9 & $10.87 \%$ \\
\hline Neither Difficult nor Easy & 5 & $19.56 \%$ \\
\hline Fairly Easy & 9 & $28.26 \%$ \\
\hline Very Easy & 13 & \\
\hline
\end{tabular}

While the total security of mobile banking and the confidentiality of the user's PIN are intricately related and dependent on each other, the research reveals quite a contradictory view among the respondents. Even though a staggering percentage of respondents believe that mobile banking in general is a secured system, as shown in table 2, they do not think the same way about the confidentiality of the PIN. It appears that, according to table 3, about thirty-eight percent of the respondents think that it is fairly or very easy to access someone's PIN without proper authorization. Some bankers do point out that more than forty percent of the respondents think it is next to impossible or very difficult to access someone's PIN without the proper authorization. Banks, however, should not ignore the other forty percent's observation who believes that it is somewhat easy to access the PIN 
and therefore must take necessary action in that area to ensure and enhance the total security of the mobile banking system.

Table 4. Registered Mobile Company for Banking Services

\begin{tabular}{|c|c|c|c|c|c|c|}
\hline & Airtel & Banglalink & Citycell & $\begin{array}{l}\text { Grameen } \\
\text { Phone }\end{array}$ & Robi & Teletalk \\
\hline Mean & 0.72 & 0.85 & 0.72 & 0.74 & 0.62 & 0.66 \\
\hline Standard Error & 0.07 & 0.05 & 0.07 & 0.06 & 0.07 & 0.07 \\
\hline Variance & 0.20 & 0.13 & 0.20 & 0.19 & 0.24 & 0.23 \\
\hline
\end{tabular}

As per our research, six registered mobile phone companies currently provide mobile banking service in Bangladesh. Our research also reveals that Banglalink has the highest contribution in mobile banking services in Bangladesh. However, it should note that the other five mobile companies mentioned in the above table also have significant contribution in the development of mobile banking services in Bangladesh.

Table 5. Trend Analysis of Mobile Banking Users

\begin{tabular}{|c|c|c|c|c|}
\hline $\begin{array}{c}\text { Anticipated } \\
\text { users (2012) }\end{array}$ & $\begin{array}{c}\text { Current users } \\
\mathbf{( 2 0 1 2 )}\end{array}$ & Growing rate (2012) & Anticipated users (2013) & $\begin{array}{c}\text { Expected growing rate } \\
\text { (2013) }\end{array}$ \\
\hline 101,890 & 184,074 & $80.66 \%$ & 364,498 & $98.22 \%$ \\
\hline
\end{tabular}

Finally, the fact that the actual number of users in 2012 were eighty percent more than the number of users the banks anticipated for the year the banks are very optimistic about the growth and, as shown in table 5, the banks were expecting almost a hundred percent growth in the number of users for the year 2013. If the banking authorities are able to provide better mobile banking services to the users the growth can be again higher than anticipation, as it was the case in 2012.

\subsection{Testing of the researchers primary assumptions}

\subsubsection{Growth speed of mobile banking in Bangladesh}

The central theme of this research is to validate the assumption that the use of mobile banking is rapidly increasing in Bangladesh and there is a great prospect of mobile banking in Bangladesh. To validate this hypothesis a question was included in the questionnaire in which the respondents were requested to indicate how fast they think mobile banking was growing - slowly, normally, or rapidly.

The researchers initially believed that at least $40 \%$ of the respondents would indicate that mobile banking was rapidly increasing. The assumption was that if more than $40 \%$ respondents believe that mobile banking was rapidly increasing than we can safely assume that mobile banking indeed is rapidly increasing. Among the forty-eight respondents, twenty-eight indicated that they believed the use of mobile banking in Bangladesh was growing rapidly. The following hypothesis testing is performed based on the responses:

Null Hypothesis $-\mathrm{H}_{0}: \mathrm{p}<=0.4$

Alternative Hypothesis $-\mathrm{H}_{1}: \mathrm{p}>0.4$

Table 6. Responses about the growth speed of mobile banking in Bangladesh (Rapidly Increasing/Normally Increasing/Slowly Increasing)

\begin{tabular}{|l|l|}
\hline Number of total respondents (sample size) & $\mathbf{4 8}$ \\
\hline Number of respondents who selected Rapidly Increasing & 28 \\
\hline Number of respondents who selected Normally Increasing & 16 \\
\hline Number of respondents who selected Slowly Increasing & 4 \\
\hline Kurtosis (of the entire sample for this question) & -0.13078 \\
\hline Respondents who chose Rapidly Increasing & \\
\hline Sample Proportion & 0.58333 \\
\hline Estimated Standard Error & 0.07071 \\
\hline Significance Level (at 95\% confidence level - one tail) & 0.05 \\
\hline Test Statistic (z) & 2.59272 \\
\hline p value & 0.00476 \\
\hline
\end{tabular}

Since the $p$ value (0.00476) in table 7 is far less than 0.05 , the null hypothesis can be rejected and it can be concluded from the data collected that mobile banking is indeed rapidly increasing in Bangladesh and there is a great prospect for mobile banking in this country.

\subsubsection{Ease of use and the prospect of becoming popular among the mass users}

One of the most important qualities of any product, especially a technological product, is the ease of use. Even though the initial users of any technology accept a higher degree of complexity, eventually the product must become easy to use for it to become acceptable by the general population or less technology savvy 
people. Moreover, we must consider the educational demography of Bangladesh. Most of the mobile users in Bangladesh have very little or no education at all. If doing mobile banking is not as simple as making a phone call using a mobile phone or listening music from a mobile phone it may not be possible to make mobile banking even moderately popular among the vast majority of the population in Bangladesh. Hence, the research focused on measuring the ease of use, or in other words, the level of complexity of using mobile banking. If mobile banking is perceived as easy to use then it will indicate that it has the opportunity to become popular in near future. Due to the strong need of simplicity in using mobile banking, the researchers were looking to see if at least $25 \%$ respondents would state that it is either simple or very simple to use mobile banking at its current state. We should remember that mobile banking in Bangladesh is still at a very infant stage. Hence, even if at least $25 \%$ respondents agree that it is easy to use at its current state, we can safely assume that mobile banking has the ability to become acceptable among the general population within a short period. Twenty-nine respondents out of the forty-eight respondents who participated in the research agreed that it is either very simple or simple to use mobile banking. The following hypothesis testing has been performed based on the responses provided by the participants:

Null Hypothesis $-\mathrm{H}_{0}: \mathrm{p}<=0.25$

Alternative Hypothesis $-\mathrm{H}_{1}: \mathrm{p}>0.25$

Table 7. Responses about the of Mobile Banking in Bangladesh (Simple or Very Simple/Neither Complex nor Simple/Complex or Very Complex)

\begin{tabular}{|l|l|}
\hline Number of total respondents (sample size) & $\mathbf{4 8}$ \\
\hline Number of respondents who selected Simple or Very Simple & 29 \\
\hline Number of respondents who selected Neither Complex nor Simple & 16 \\
\hline Number of respondents who selected Complex or Very Complex & 3 \\
\hline Kurtosis (of the entire sample for this question) & -0.360308 \\
\hline Respondents who chose Simple or Very Simple & 0.60417 \\
\hline Sample Proportion & 0.06250 \\
\hline Estimated Standard Error & 0.1 \\
\hline Significance Level (at 95\% confidence level - two tail) & 5.66667 \\
\hline Test Statistic (z) & 0.00000001 \\
\hline p value & \\
\hline
\end{tabular}

Based on the above analysis in table 8 , we can reject the null hypothesis with $99 \%$ confidence level. Hence, we can conclude that using mobile banking in Bangladesh at its current state is simple enough for it to become popular among users who may not be well educated or technology savvy.

\subsubsection{The perception of security and the prospects of growth}

The perception of security when it comes to dealing with money is of paramount importance. People keep or invest their money in banks because they believe it is more secured than keeping the money at their houses or investing in the money on their own. Most of the time during the history of banking people had almost unconditional faith on banks to be secure. However, those days have passed. With the recent worldwide financial crisis when the biggest defaulters were banks, people now have become very reluctant to have unconditional faith on banks and do not believe that everything their banks introduce is safe and secure. Therefore, the users of mobile banking must perceive it as a secure system for it to capture the larger audience. To assess the current status the researchers were looking to see if at least $70 \%$ respondents would agree that mobile banking is fairly secured or highly secured. The high percentage (70\%) for this hypothesis was selected due to the very high importance of security usually required by bank clients in recent days. To gauge the perception, the participants were given five choices ranging from highly secured to highly unsecured. Among the forty-seven respondents who answered the specific question forty-three respondents indicated that they thought mobile banking in Bangladesh was either highly secured or fairly secured. The following analysis and hypothesis testing have been performed based on the responses provided:

Null Hypothesis $-\mathrm{H} 0: \mathrm{p}<=0.7$

Alternative Hypothesis - H1: $\mathrm{p}>0.7$

Table 8. Responses about the security of Mobile Banking in Bangladesh (Highly or Fairly Secured / Neither Secured nor Unsecured / Highly or Fairly Secured)

\begin{tabular}{|l|l|}
\hline Number of total respondents (sample size) & $\mathbf{4 7}$ \\
\hline Number of respondents who selected Highly Secured or Fairly Secured & 43 \\
\hline Number of respondents who selected Neither Secured nor Unsecured & 4 \\
\hline & 0 \\
\hline
\end{tabular}


Implementation of Mobile Banking in Bangladesh: Opportunities and Challenges

\begin{tabular}{|l|l|}
\hline Kurtosis (of the entire sample for this question) & -0.40239 \\
\hline Respondents who chose Highly Secured or Fairly Secured & 0.91489 \\
\hline Sample Proportion (who chose Highly Secure or Fairly Secured) & 0.06684 \\
\hline Estimated Standard Error & 0.1 \\
\hline Significance Level (at 95\% confidence level - two tail) & 3.21487 \\
\hline Test Statistic (z) & 0.001305 \\
\hline p value & \\
\hline
\end{tabular}

Since the p value (0.001305) in table 9 is far less than the significance level $(0.1)$, the null hypothesis can be rejected and it can be concluded the at least $70 \%$ respondents perceive mobile banking as highly or fairly secured. This result is of course very promising given that such a great percentage of people believe that mobile banking is at least fairly secured.

\section{Recommendations and Conclusion}

Mobile banking has become an important phenomenon in the banking sector of Bangladesh and it will continue to grow manifold, as information technology in the country gets better. However, there are concerns about the security of the mobile banking with regard to the confidentiality of PIN. These concerns, if not addressed properly within reasonable time, can put this very successful, innovative, and creditable financial service at risk. Here are some recommendations that will help abate the current level of challenges and difficulties that the implementation is facing:

i. Mobile banking should be easily accessible by the users; this should be in terms of approach or convenience, availability, understanding and suitability.

ii. The users should not need the service of a specialist to conduct their transaction using mobile banking regardless of their educational or professional qualifications.

iii. The authorities should ensure the users about the security of mobile banking as well as attempt to renew lost materials most especially where there is loss of material due to corruption of data in the system.

iv. The service providers should have failsafe system to recover from loss of material and information.

v. Uninterrupted power supply and internet connectivity is essential for the success of mobile banking and the banking industry should work closely with the government to ensure that.

Finally, it was not long ago when the first mobile handset came to Bangladesh and within only a decade the people of Bangladesh have heavily adapted the use of mobile phones. The increase in the number of mobile phone users perhaps even surprised the biggest optimists. In addition, Bangladeshi people have also shown a keen interest to use mobile phones for multiple purposes such as listening music and sending text messages. Therefore, it can be confidently assumed that if the mobile phones offer another convenient, easy to use, and secured service, the people of Bangladesh would love to use that service. The research proves that the people of Bangladesh has indeed embraced this new technology at a great speed and if the service providers pay due attention to fix the problems the users currently facing, mobile banking may become as popular in Bangladesh as it has in many other countries in the developed world.

\section{Reference}

[1]. Weber Rolf H and DarbellayAline: Legal issues in mobile banking, Journal of Banking Regulation (2010) 11, 129-145. doi: $10.1057 /$ jbr.2009. p. 16.

[2]. Donner, Jonathan and Tellez, Camilo 2008, 'Mobile banking and economic development: linking adoption, impact, and use', Asian Journal of Communication, Vol. 18, no.4, pp. 318-322

[3]. Klein Michael,Mayer Colin: Mobile banking and financial inclusion : the regulatory lessons, 01 May 2011

[4]. Centeno, C 2004, 'Adoption of internet services in the acceding and countries, lessons from the internet banking case', Telematics and Informatics, 21, pp. 293-315

[5]. Mousumi, Fouzia and Jamil, Subran 2010, 'Push-pull service offering SMS based mobile banking system in context of Bangladesh', International Arab Journal of e-Technology, Vol. 1, no.3, pp. 79-88

[6]. Hasan, A, H, M, Baten, Md. Azizul, Kamil, Anton Abdulbasah and Parveen, Sanjida 2010, 'Adoption of e-banking in Bangladesh: an exploratory study', AFRICAN Journal of Business Management, Vol. 4, no. 13, pp. 2718-27 KPMG 1999, Internet financial services survey

[7]. Taylor \& Francis Group 2008 'Research approaches to mobile use in the developing world: a review of the literature', The Information Society, Vol. 24, Issue no. 3, pp. 2-41

[8]. Mobile marketing association 2009, 'Mobile banking overview (NA)', January 2009.

[9]. Khan, Rahman, Md. Atiqur and Karim, Md.Masud 2011, 'E-banking and extended risks: how to deal with the challenge?',Working Paper, Finance and Banking, R.U, Ref. No. FIN 0806, 